\title{
Secure Online Voting System using Visual Cryptography
}

\section{Meher Gayatri Devi TIWARI* and Anil Kumar KAKELLI}

\author{
School of Computer Science and Engineering, Vellore Institute of Technology, Vellore 632014, India
}

('Corresponding author's e-mail: mehergayatri17@gmail.com)

Received: 24 September 2019, Revised: 22 May 2021, Accepted: 29 May 2021

\begin{abstract}
The development of a secure online voting system using visual cryptography is highly essential for present voting systems. Based on the current requirements and design aspects of an existing online voting system, emerging technologies are required in online voting schemes, and these are examined in this work. The emerging cryptographic techniques which are suitable for secure online voting systems are analyzed. Techniques like password hashed-based schemes, visual cryptography, and threshold decryption cryptosystem are highlighted for secure online voting systems. Visual cryptography (VC) is a technique where visual information can be encrypted on the user side, with the information decrypted on the admin side, which can be helpful in allowing participation in voting systems securely and ensuring fast vote counting and monitoring of the voting process to achieve high accuracy while being scam-free. The proposed secure online voting system using visual cryptography is efficiently developed using Python and achieves better performance on minimum software and hardware configuration systems.
\end{abstract}

Keywords: Visual Cryptography, E-voting, Security, Techniques, Performance

\section{Introduction}

Visual cryptography (VC) is a technique where visual information, such as texts, pictures, videos, etc., can be encrypted efficiently, with the decryption of the information being as a visual image. Visual secret-keeping is a scheme that securely shares a system [1,2]. It splits the data and shares it, rather than encrypting it and saving it in a single place. Hence, there are several ways for securing the data, such as storing it in two places by splitting it into two shares or " $n$ " shares. Most of the existing research work has used two secret shares, where one is provided to the voter using email or the computer being logged in, and the other is stored in the database of the voting system. This helps the system be transparent and also allows the system to run efficiently $[3,4]$. There is no ciphertext, as the shares act as the same. VC is the expansion of the requirement with limited memory. It is completely secure and increases the efficiency of working, as it involves a regulatory structure. VC can be used for a variety of systems and applications [5], which shows a greater evolution and has larger impact on growth.

E-voting is a process of voting using the internet or an electronic way for the easy casting of votes, accurate counting of the votes, and monitoring; it is professional and is also scam-free. This system stores the data on a computer system to make the voting system be faster and have also flawless counting [6]. Existing voting systems can allow multiple casting of votes and, hence, the process is enumerated as online voting and as better e-voting. The existing e-voting systems have the mechanism of VC. Some of the other techniques, like steganography, where encryption algorithms are combined with VC, have been used for better security [7]. The evaluation of the system needs to be very particular and, hence, a few more techniques and the involvement of admin are included to avoid natural forgery. This type of system can be used in both lower and higher forums of elections. People away from their native places can also vote with the accuracy of an authorized person, who has to be elected for the particular position [8]. As a result of the enumeration towards the system, the researchers and the developers who designing a system 
http://wjst.wu.ac.th

should focus on security with high priority, as well as ensuring the system is user-friendly, with high performance, cost-efficiency, speed, and usability.

\section{Literature survey}

Comparative analysis of the various online voting systems: Objectives, techniques, and algorithms (Table 1).

Table 1 Comparative analysis of the various online voting systems: Objectives, techniques, and algorithms.

\begin{tabular}{|c|c|c|c|c|}
\hline Title & Proposed Method & Objective & $\begin{array}{c}\text { Techniques/ Algorithms } \\
\text { used }\end{array}$ & Result \\
\hline $\begin{array}{l}\text { Remote voting } \\
\text { system- for corporate } \\
\text { companies using } \\
\text { visual cryptography }\end{array}$ & $\begin{array}{l}\text { This paper aims to allow } \\
\text { the casting of votes while } \\
\text { the confidential and } \\
\text { critical conditions of } \\
\text { corporate decisions are } \\
\text { addressed in a very } \\
\text { efficient way. This } \\
\text { particular method makes it } \\
\text { so flexible that it allows } \\
\text { casting of votes from any } \\
\text { remote place, and during } \\
\text { times when key } \\
\text { stakeholders of the } \\
\text { election process are } \\
\text { unavailable in the } \\
\text { workplace. }\end{array}$ & $\begin{array}{l}\text { Voting via the internet, } \\
\text { keeping track of the } \\
\text { system, designing proper } \\
\text { security goals, } \\
\text { maintaining transparency } \\
\text { while compared to the } \\
\text { present work, making the } \\
\text { work a success [9], and } \\
\text { bringing over accurate } \\
\text { results. }\end{array}$ & $\begin{array}{l}\text { From the lowercase letters } \\
\text { and also the numbers } \\
\text { available, } 12 \text { characters are } \\
\text { selected randomly and } \\
\text { encoded with a } 64 \text {-bit key. } \\
\text { SSL certification [10] is } \\
\text { asked for, to be checked by } \\
\text { the users by sending them } \\
\text { a valid Ki value by the } \\
\text { election server. This kind } \\
\text { of protocol is flexible and } \\
\text { capable of serving to both } \\
\text { authenticate the voter with } \\
\text { the election server and vice } \\
\text { versa. }\end{array}$ & $\begin{array}{l}\text { From the result of this } \\
\text { work, a voting system } \\
\text { should be based on } \\
\text { security measures and } \\
\text { also on the accuracy of } \\
\text { voting. The system } \\
\text { should be tested to } \\
\text { make sure that it } \\
\text { provides the process } \\
\text { with reliability and } \\
\text { intuitive indications for } \\
\text { the voter. }\end{array}$ \\
\hline $\begin{array}{l}\text { Developing a visual } \\
\text { cryptography tool for } \\
\text { Arabic text }\end{array}$ & $\begin{array}{l}\text { This paper involves } \\
\text { Arabic language exposure } \\
\text { towards the VC technique. } \\
\text { According to the author, } \\
\text { there are many studies } \\
\text { have researched VC, but } \\
\text { Arabic has not been } \\
\text { focused on; Arabic } \\
\text { nowadays holds a lot of } \\
\text { importance, and in many } \\
\text { places the language is } \\
\text { used [4]. Henceforth, the } \\
\text { author puts VC techniques } \\
\text { towards it. The tool } \\
\text { designed can be similarly } \\
\text { followed for electronic } \\
\text { voting, anti-phishing, } \\
\text { Captcha, watermarking, } \\
\text { biometric privacy, online } \\
\text { payment systems, and } \\
\text { digital signature in the } \\
\text { Arabic environment. }\end{array}$ & $\begin{array}{l}\text { Arabic is written from } \\
\text { right to left, unlike } \\
\text { English which is written } \\
\text { from left to right. The } \\
\text { Arabic letters look } \\
\text { complicated as they seem } \\
\text { to be attached when } \\
\text { written or printed. The } \\
\text { study concludes that a lot } \\
\text { of techniques have been } \\
\text { developed to identify and } \\
\text { keep data safe and } \\
\text { legible, as there are many } \\
\text { Arabic-speaking internet } \\
\text { users. }\end{array}$ & $\begin{array}{l}\text { The size of the image is set } \\
\text { in canvas as a function. } \\
\text { The location is drawn and } \\
\text { the background color is set } \\
\text { to be white. Later, a } \\
\text { createTextImage() [11] } \\
\text { function is used for the text } \\
\text { to be embedded and } \\
\text { created in Arabic text. The } \\
\text { position for the image is } \\
\text { chosen randomly as the } \\
\text { text is written. The } \\
\text { limitation of the relatively } \\
\text { small number of } \\
\text { participants is considered. }\end{array}$ & $\begin{array}{l}\text { The work shows the } \\
\text { average time and } \\
\text { effectiveness that is } \\
\text { recognized in the text } \\
\text { and the satisfaction } \\
\text { with it. The tool is also } \\
\text { advanced and is } \\
\text { capable of being } \\
\text { helpful in practical } \\
\text { security appliances like } \\
\text { Arabic CAPTCHAs } \\
\text { [12]. This way, the } \\
\text { study is also an } \\
\text { enhanced method of } \\
\text { understanding the } \\
\text { language, which is } \\
\text { growing efficient with } \\
\text { its usability. }\end{array}$ \\
\hline $\begin{array}{c}\text { A novel approach for } \\
\text { online voting system } \\
\text { using visual }\end{array}$ & $\begin{array}{l}\text { This paper discusses the } \\
\text { advantages, disadvantages, } \\
\text { and comparison of a few }\end{array}$ & $\begin{array}{l}\text { It is helpful for people to } \\
\text { vote from anywhere, as } \\
\text { they need not wait in }\end{array}$ & $\begin{array}{c}\text { A person need not go } \\
\text { anywhere; they can stay } \\
\text { home and cast a vote. This }\end{array}$ & $\begin{array}{l}\text { As a result, it is easy } \\
\text { for voters to vote via } \\
\text { the internet. Counting }\end{array}$ \\
\hline
\end{tabular}




\begin{tabular}{|c|c|}
\hline Title & Proposed Method \\
\hline $\begin{array}{l}\text { cryptography and face } \\
\text { detection }\end{array}$ & $\begin{array}{l}\text { e-voting systems. It also } \\
\text { proposes a system that } \\
\text { overcomes a drawback } \\
\text { where VC can be } \\
\text { introduced along with face } \\
\text { detection, as it can } \\
\text { provides a more suitable } \\
\text { way of voting, is user } \\
\text { friendly, and has more } \\
\text { security. }\end{array}$ \\
\hline
\end{tabular}
security.

Objective
them not to bring an
instinct if not voting
because of work, as it
kes an urge to a person
aking lethargic. To get
full number of votes.
e system involves face
ection [14] and VC as

the algorithm technique.
Visual cryptography in internet voting for extended security

\section{This paper aims for e-} voting as it makes the process automatic and easy to vote from anywhere across the limits of voting. $\mathrm{VC}$ and steganography are used to keep secrecy in advance. A secret password is enabled inside one image, which is split in two parts, where both are shared at once by the user to allow voting without invasion.

This system becomes userfriendly as it is safe and admin permissions are separate from the users. It allows the casting of votes from any location without any problems.

Online polling system This paper offers benefits using extended visual such as cost efficiency and cryptography increase of voters. In simple terms, it allows people to vote from wherever they are, irrespective of their location, along with security. The VC technique gives rise to a more secure way of online polling, and considers human factors in a careful way.

\begin{tabular}{cc}
\hline $\begin{array}{c}\text { Online voting system } \\
\text { using visual }\end{array}$ & $\begin{array}{c}\text { The work compares the } \\
\text { existing e-voting systems, }\end{array}$
\end{tabular}
cryptography and face their drawbacks, and also
Techniques/ Algorithms used

makes it easy to allow the maximum amount of votes to be collected. Hence, it is convenient in whichever way the vote can be cast [13]. E-voting becomes secure with some safe algorithms being used and ensures people cast votes only once. Areas involved include providing security, avoiding phishing

attackers, and also decreasing bogus voting.

\section{Elections happen in both 1 . User registers.} ways, as it helps in appointing the right person without any partiality [15]. Since elections are restricted towards a location or area, e-voting removes

the barrier of

inconvenience.

This is being done with $\mathrm{VC}$, along with sufficient security.

It becomes very flexible

for the vote to be cast from any remote place, even when voters are unavailable for the process. This kind of feature is provided by VC [17]. It also takes care of human factors and also the security measures of voting. rejected. image.

8. User logs out published. large- and small-scale

2. Admin checks and views with ID proof. 3. Validity to vote is accepted; otherwise

4. User login with credentials allows the downloading of a security

5. User sends email ID and upload both the shares.

6. Admin rechecks if it matches with the VC.

7. User votes only once and cannot vote again even if any mistake is made. automatically and can view the result only once it is

It shares the secret image As a result of this work,
in a registration phase as a the government is part of creating security spending a lot of money within a server [18]. Here, on the election; apart the technique of $\mathrm{VC}$ is from this it is now used as a security scheme. known that the voting This scheme allows the percentage is less and giving of credentials to a there is a chance to stop user, which is accepted by fraud [19]. The the server only if the percentage of voting correct ones are entered for can be increased; also, participation in voting. the amount spent can be reduced.

\begin{tabular}{ccc}
$\begin{array}{c}\text { Some of the misleading } \\
\text { effects in the present } \\
\text { methods are privacy- }\end{array}$ & $\begin{array}{c}\text { Fingerprinting as a way of } \\
\text { voting has become an } \\
\text { automated way of personal }\end{array}$ & $\begin{array}{c}\text { As a result of this work, } \\
\text { the sharing of some } \\
\text { prominent technologies }\end{array}$ \\
\hline
\end{tabular}




\begin{tabular}{|c|c|c|c|c|}
\hline Title & Proposed Method & Objective & $\begin{array}{c}\text { Techniques/ Algorithms } \\
\text { used }\end{array}$ & Result \\
\hline detection- a survey & $\begin{array}{c}\text { their advantages. It } \\
\text { proposes a mechanism } \\
\text { where VC along with face } \\
\text { detection is } \\
\text { collaboratively used. This } \\
\text { provides more efficiency, } \\
\text { appropriate voting, and a } \\
\text { user-friendly and secure } \\
\text { mechanism. }\end{array}$ & $\begin{array}{l}\text { breach and fake votes, } \\
\text { resulting in distortion and } \\
\text { disturbance in an election } \\
\text { and ballot snatching [20]. } \\
\text { The work is effective and } \\
\text { efficient, and enumerates } \\
\text { the system as estimated. }\end{array}$ & $\begin{array}{l}\text { identification which allows } \\
\text { verification and also } \\
\text { security. Rather than this, } \\
\text { face detection using VC is } \\
\text { used to make it easier and } \\
\text { more feasible to vote from } \\
\text { anywhere [21]. The secret } \\
\text { sharing scheme does not } \\
\text { allow any information to } \\
\text { be exposed. }\end{array}$ & $\begin{array}{l}\text { can solve the voting } \\
\text { methods. The efficient } \\
\text { mechanism of VC } \\
\text { reduces the efforts and } \\
\text { also makes the system } \\
\text { run smoothly. It also } \\
\text { provides security and } \\
\text { mutual authentication } \\
\text { for the client and server } \\
\text { involved. }\end{array}$ \\
\hline $\begin{array}{c}\text { Anti-phishing } \\
\text { I-voting system using } \\
\text { visual cryptography }\end{array}$ & $\begin{array}{l}\text { This paper aims for voting } \\
\text { to be easy from remote } \\
\text { places. A user can cast } \\
\text { vote using credentials with } \\
\text { security. A password is } \\
\text { generated using a VC } \\
\text { technique. The election } \\
\text { committee sends two } \\
\text { secret keys, one user and } \\
\text { one system. Both are } \\
\text { matched and then a vote } \\
\text { can be cast. This is from } \\
\text { the VC technique. It is } \\
\text { supposed to be secure and } \\
\text { has to be kept away from } \\
\text { anyone; otherwise, it will } \\
\text { not be accepted. Phishing } \\
\text { involves attempting to get } \\
\text { personal information in } \\
\text { any possible way. It } \\
\text { mostly happens by email } \\
\text { or spoofing by users } \\
\text { whose information can be } \\
\text { used in a fake website. }\end{array}$ & $\begin{array}{l}\text { Network security has } \\
\text { been growing on a larger } \\
\text { scale [22]. It is used for } \\
\text { accessing data with a } \\
\text { secure platform where the } \\
\text { admin rights are given } \\
\text { with proper credentials. } \\
\text { Phishing is the stealing of } \\
\text { private and sensitive } \\
\text { information for malicious } \\
\text { reasons. The data stolen } \\
\text { by phishing can be used } \\
\text { in any forum in a fake } \\
\text { format. }\end{array}$ & $\begin{array}{l}\text { A method is proposed to } \\
\text { prevent and detect } \\
\text { phishing. It is based on } \\
\text { Anti-phishing Image } \\
\text { Captcha using the VC } \\
\text { technique [23]. Only } \\
\text { authorized people will be } \\
\text { allowed to vote where it } \\
\text { prevents phishing. The } \\
\text { server picks a text image } \\
\text { as a password for } \\
\text { registration, which is the } \\
\text { same as used for login. } \\
\text { Then, the secret key should } \\
\text { be shared. Hence, the } \\
\text { username and captcha can } \\
\text { be generated, and phishing } \\
\text { can be prevented as per the } \\
\text { authentication being done. } \\
\text { Verification is made, } \\
\text { which has to be prominent } \\
\text { for anti-phishing. }\end{array}$ & $\begin{array}{l}\text { As a result of the paper, } \\
\text { the VC technique is } \\
\text { used to prevent } \\
\text { phishing. Once done, it } \\
\text { can be used in many } \\
\text { large- and small-scale } \\
\text { places. This safely } \\
\text { allows the casting of } \\
\text { votes so as to be } \\
\text { utilized in all the places } \\
\text { for casting votes. The } \\
\text { voter can cast only once } \\
\text { and cannot redo it. The } \\
\text { phishing website does } \\
\text { not display an image if } \\
\text { it is real [24]. An } \\
\text { intruder is not allowed } \\
\text { to enter the website } \\
\text { even by knowing the } \\
\text { credentials. }\end{array}$ \\
\hline $\begin{array}{c}\text { Internet voting system } \\
\text { using Visual } \\
\text { Cryptography }\end{array}$ & $\begin{array}{l}\text { This paper helps in more } \\
\text { security using the VC } \\
\text { technique, also using a } \\
\text { secure password. } \\
\text { "ONLINE VOTING } \\
\text { SYSTEM" is the latest } \\
\text { technology. It makes it } \\
\text { easy to vote from } \\
\text { anywhere. All the data is } \\
\text { stored in a server with } \\
\text { high security. }\end{array}$ & $\begin{array}{l}\text { E-voting becomes easier } \\
\text { and also involves more } \\
\text { people [25]. It makes it } \\
\text { user-friendly and } \\
\text { particular in providing } \\
\text { the voters with reliability. } \\
\text { It is proposed with the } \\
\text { VC technique. }\end{array}$ & $\begin{array}{l}\text { It is proposed that this } \\
\text { system will be used in } \\
\text { many lower and higher } \\
\text { places for voting as it is } \\
\text { cost-efficient and uses time } \\
\text { management. It has a } \\
\text { client-server system [26]. } \\
\text { Both the admin and the } \\
\text { user have different rights } \\
\text { as required. Data is stored } \\
\text { and removed within the } \\
\text { stipulated time. }\end{array}$ & $\begin{array}{l}\text { As a result, this system } \\
\text { can be used in a } \\
\text { company's election or } \\
\text { in government voting; } \\
\text { it will be very easy for } \\
\text { all citizens to vote in e- } \\
\text { voting method from } \\
\text { anywhere they are as it } \\
\text { becomes secure by } \\
\text { using the VC technique } \\
\text { [27]. }\end{array}$ \\
\hline $\begin{array}{l}\text { Novel authentication } \\
\text { system using Visual } \\
\text { Cryptography }\end{array}$ & $\begin{array}{l}\text { This paper aims to } \\
\text { compare the VC technique } \\
\text { with some of its methods } \\
\text { like pixel expansion, } \\
\text { number of shares, size, } \\
\text { quality of reconstructed } \\
\text { image, etc. It improves } \\
\text { cost-efficiency, along with }\end{array}$ & $\begin{array}{l}\text { Security is taken care of, } \\
\text { where nothing can be } \\
\text { faked. This technique can } \\
\text { also be used in safe } \\
\text { systems for debit cards. } \\
\text { This system helps in } \\
\text { protecting fraud of the } \\
\text { card [29]. }\end{array}$ & $\begin{array}{l}\text { This full method is similar } \\
\text { to handling by the CA } \\
\text { (Chartered Accountant) } \\
\text { and the bank. Every } \\
\text { authorization is given } \\
\text { through the CA and the } \\
\text { bank accepts the } \\
\text { authorization, then each }\end{array}$ & $\begin{array}{l}\text { A result of this system } \\
\text { brings in the VC } \\
\text { technique of color, } \\
\text { which was proposed to } \\
\text { have more security } \\
\text { towards the system to } \\
\text { prevent forgery. This } \\
\text { can be put into systems }\end{array}$ \\
\hline
\end{tabular}




\begin{tabular}{|c|c|c|c|c|}
\hline Title & Proposed Method & Objective & $\begin{array}{c}\text { Techniques/ Algorithms } \\
\text { used }\end{array}$ & Result \\
\hline & $\begin{array}{c}\text { the level of security it } \\
\text { upholds. }\end{array}$ & & $\begin{array}{l}\text { request made by the bank } \\
\text { is confirmed by the CA } \\
\text { from the customer and } \\
\text { processed for verification } \\
\text { [28]. }\end{array}$ & $\begin{array}{l}\text { such as credit/ debit } \\
\text { cards, and also voting. }\end{array}$ \\
\hline $\begin{array}{l}\text { E-voting system using } \\
\text { visual cryptography } \\
\text { secure multi-party } \\
\text { computation }\end{array}$ & $\begin{array}{l}\text { This paper aims for } \\
\text { identification proofs to be } \\
\text { monitored so that any } \\
\text { fakes can be prevented } \\
\text { and cross-checked to deny } \\
\text { the approval. A multi- } \\
\text { party system is used to } \\
\text { keep the system secure, } \\
\text { and also allows it to be } \\
\text { reliable and transparent. It } \\
\text { also monitors so that a } \\
\text { person is only allowed to } \\
\text { vote once. The four phases } \\
\text { of the system used are: } \\
\text { 1. The voter's enrolment, } \\
\text { 2. Voter's authentication, } \\
\text { 3. Vote casting and } \\
\text { recording, and } \\
\text { 4. Vote counting and } \\
\text { election result publication. }\end{array}$ & $\begin{array}{l}\text { It provides a model for } \\
\text { time complexity and } \\
\text { smoothness of voting, as } \\
\text { it helps voting to be done } \\
\text { from anywhere [30]. } \\
\text { Security is also kept as } \\
\text { the highest priority. The } \\
\text { system uses the VC } \\
\text { technique and biometrics } \\
\text { to allow authentication to } \\
\text { be kept in a very relevant } \\
\text { and structured way. }\end{array}$ & $\begin{array}{l}\text { The process is about } \\
\text { constructing and } \\
\text { reconstructing biometrics, } \\
\text { as each example is unique; } \\
\text { there are two parts. One } \\
\text { part is stored in the voter's } \\
\text { ID card, and the other is in } \\
\text { the database; hence, both } \\
\text { will be activated only if it } \\
\text { is done live to prevent } \\
\text { forgery [31]. Also, the } \\
\text { algorithm that is used does } \\
\text { not allow reconstruction if } \\
\text { there is only one part } \\
\text { available. Here, security } \\
\text { plays a very important } \\
\text { role. }\end{array}$ & $\begin{array}{l}\text { As a result of the } \\
\text { system that is used, it is } \\
\text { known that two ways of } \\
\text { authentication make the } \\
\text { votes and the voters } \\
\text { secure and prevent } \\
\text { falsification. It } \\
\text { improves the system by } \\
\text { involving the data } \\
\text { being stored in multiple } \\
\text { places rather than } \\
\text { putting it in one place, } \\
\text { which makes it easy for } \\
\text { it to be traced. Hence, } \\
\text { this is one of the recent } \\
\text { and the most effective } \\
\text { systems. }\end{array}$ \\
\hline $\begin{array}{l}\text { Visual cryptography } \\
\text { in internet voting } \\
\text { system }\end{array}$ & $\begin{array}{l}\text { This paper brings in a } \\
\text { system which involves the } \\
\text { technique of VC into the } \\
\text { internet voting system } \\
\text { (IVC). It helps in voting } \\
\text { from anywhere, and also } \\
\text { focuses on the security } \\
\text { measures that are taken for } \\
\text { the system to stay } \\
\text { confidential. Only the } \\
\text { correct credentials will } \\
\text { allow the user to use the } \\
\text { portal. A password is } \\
\text { generated by two2 merge } \\
\text { shares (Black and White } \\
\text { share) from the VC } \\
\text { technique. }\end{array}$ & $\begin{array}{l}\text { The system provides two } \\
\text { shared secrets, where one } \\
\text { is given to the voter and } \\
\text { one is in the database that } \\
\text { is launched [32]. Hence, } \\
\text { the voter has to log in } \\
\text { with the right credentials } \\
\text { and get into the system to } \\
\text { vote. It is kept securely so } \\
\text { that forgery and } \\
\text { falsification can be } \\
\text { eliminated from the } \\
\text { system. }\end{array}$ & $\begin{array}{l}\text { The VC technique used to } \\
\text { implement high security in } \\
\text { the system is a } 2 \text { to } 2 \\
\text { sharing system, as there } \\
\text { are many more sharing } \\
\text { techniques. Here, even if } \\
\text { one part of the secret key is } \\
\text { present, cracking the } \\
\text { system is not allowed } \\
\text { unless the other is present. } \\
\text { This is one of the most } \\
\text { secure mechanisms for } \\
\text { storing and obtaining a } \\
\text { vote from an enrolled } \\
\text { citizen [33]. The VC } \\
\text { technique is used to } \\
\text { authenticate the right one. }\end{array}$ & $\begin{array}{l}\text { The method and the } \\
\text { systems used in this } \\
\text { project allow a person } \\
\text { to vote from anywhere } \\
\text { without any disturbance } \\
\text { or inconvenience. The } \\
\text { system is secure and } \\
\text { cross-checks } \\
\text { identification proofs so } \\
\text { that the user does not } \\
\text { falsify ID. Time } \\
\text { complexity and cost } \\
\text { efficiency have also } \\
\text { been considered as a } \\
\text { matter of fact. }\end{array}$ \\
\hline $\begin{array}{l}\text { Online voting } \\
\text { verification with } \\
\text { cryptography and } \\
\text { steganography } \\
\text { approaches }\end{array}$ & $\begin{array}{l}\text { This is a system of e- } \\
\text { voting with VC and } \\
\text { steganography techniques. } \\
\text { Users enroll and learn } \\
\text { about the process step by } \\
\text { step; nothing will be } \\
\text { hidden or be flawed. The } \\
\text { system makes the process } \\
\text { secure and it is also cost } \\
\text { and time-efficient. It } \\
\text { allows a person to vote }\end{array}$ & $\begin{array}{l}\text { The system has } 3 \text { main } \\
\text { processes that are } \\
\text { undergone in the system } \\
\text { [34]. The steps are } \\
\text { registration and } \\
\text { authentication, tallying, } \\
\text { and verification of vote. } \\
\text { Eligibility is checked } \\
\text { with the email ID and } \\
\text { forgery is denied. }\end{array}$ & $\begin{array}{l}\text { An E2E (end-to-end) } \\
\text { voting system is } \\
\text { constructed with the help } \\
\text { of the image } \\
\text { steganography technique } \\
\text { of DCT co-efficient, which } \\
\text { is efficient than the other } \\
\text { techniques that are } \\
\text { available for data hiding } \\
\text { [35]. This kind of security } \\
\text { is highly secure and makes }\end{array}$ & $\begin{array}{c}\text { As a result of the } \\
\text { system, a lot of } \\
\text { vulnerabilities have } \\
\text { been overcome. It helps } \\
\text { in cost efficiency and } \\
\text { also in faster } \\
\text { performance. Some } \\
\text { benefits are } \\
\text { trustworthiness, } \\
\text { reduction of other } \\
\text { hardware use, particular }\end{array}$ \\
\hline
\end{tabular}


http://wjst.wu.ac.th

\begin{tabular}{|c|c|c|c|c|}
\hline Title & Proposed Method & Objective & $\begin{array}{c}\text { Techniques/ Algorithms } \\
\text { used }\end{array}$ & Result \\
\hline & from any place of limits. & & $\begin{array}{l}\text { it very difficult for a forger } \\
\text { to find original data. This } \\
\text { way, data is stored in } \\
\text { multiple fragments and } \\
\text { places with VC and is also } \\
\text { kept encrypted. }\end{array}$ & $\begin{array}{l}\text { device procurement, } \\
\text { installation, upgrades, } \\
\text { and maintenance, } \\
\text { which allow the system } \\
\text { to be secure. }\end{array}$ \\
\hline $\begin{array}{l}\text { Implementation and } \\
\text { evaluation of } \\
\text { steganography-based } \\
\text { online voting system }\end{array}$ & $\begin{array}{l}\text { This paper is one of the } \\
\text { most recent and best; it } \\
\text { involves many techniques, } \\
\text { such as E2E } \\
\text { steganography and VC for } \\
\text { security. The encryption is } \\
\text { hash-based and decryption } \\
\text { is threshold-based. } \\
\text { Performance and usability } \\
\text { are improved. A voter can } \\
\text { vote from any place as the } \\
\text { limits will also be featured } \\
\text { as per the officials. }\end{array}$ & $\begin{array}{l}\text { This is a type of client- } \\
\text { server process where the } \\
\text { vote can only be cast } \\
\text { once, and only by the } \\
\text { registered user, as there } \\
\text { will be verification [36]. } \\
\text { On the other hand, the } \\
\text { server is left up to the } \\
\text { trustworthy environment } \\
\text { to be liable to the system. }\end{array}$ & $\begin{array}{l}\text { The method uses image } \\
\text { steganography and VC is } \\
\text { more secure, with forgery } \\
\text { impossible. Three factors } \\
\text { of monitoring are } \\
\text { included- voter, polling } \\
\text { officer, and system admin. } \\
\text { The system of security } \\
\text { here is different; in normal } \\
\text { cryptography a ciphertext } \\
\text { is given, but here, a } \\
\text { stegno-object [37] is } \\
\text { released, which is more } \\
\text { secure. }\end{array}$ & $\begin{array}{l}\text { Firstly, this system was } \\
\text { put into a drill, and then } \\
\text { a survey was taken and } \\
\text { then implemented. } \\
\text { Secondly, the system } \\
\text { has two shared secrets } \\
\text { which are not kept in } \\
\text { one place; one with a } \\
\text { user and the other in the } \\
\text { server. Hence, the } \\
\text { system cannot be easily } \\
\text { fooled. This makes the } \\
\text { system user-friendly, } \\
\text { secure, high } \\
\text { performing, cost and } \\
\text { time-efficient, and also } \\
\text { easily usable. }\end{array}$ \\
\hline
\end{tabular}

\section{Proposed algorithm}

Table 2 explains the algorithm used to acquire the connection of server and client. As per the algorithm, after successful connection establishment between the server and client [38], the required information is gathered from a user through a few questionnaires, as per the protocol of user registration. Thereafter, a visual image will be sent to the user for the next level of the process, as mentioned in the next algorithm.

Table 2 Proposed secure online voting system using VC.

$$
\begin{aligned}
& \text { Algorithm: } \\
& \text { 1. Start } \\
& \text { 2. Image encryption } \\
& \text { 3. Input } \leftarrow \text { hidden Image. } \\
& \text { 4. Output } \rightarrow \text { Encrypted Image. } \\
& \text { 5. Choose input } R G B \text { image } \\
& \quad \text { Separate } R-G-B \text { Channels } \\
& \text { 6. Each channel encrypted } \rightarrow \text { receive } 8 \text { shares using key }(\mathrm{Ki}) \\
& \text { 7. } \text { From step } 5 \text {, result } 24 \text { shares } \\
& \text { 8. } 8 \text { shares of each channel compress to } 3 \text { shares. } \\
& \text { 9. Output: encrypted image } \\
& \text { 10. End }
\end{aligned}
$$




\section{Module 2: Shares of password}

Some mandatory data, along with email IDs, are required from the user/client for user authorization. The secure key share will be sent to the registered user email ID, and another share is stored in the database, as shown in Figure 3.

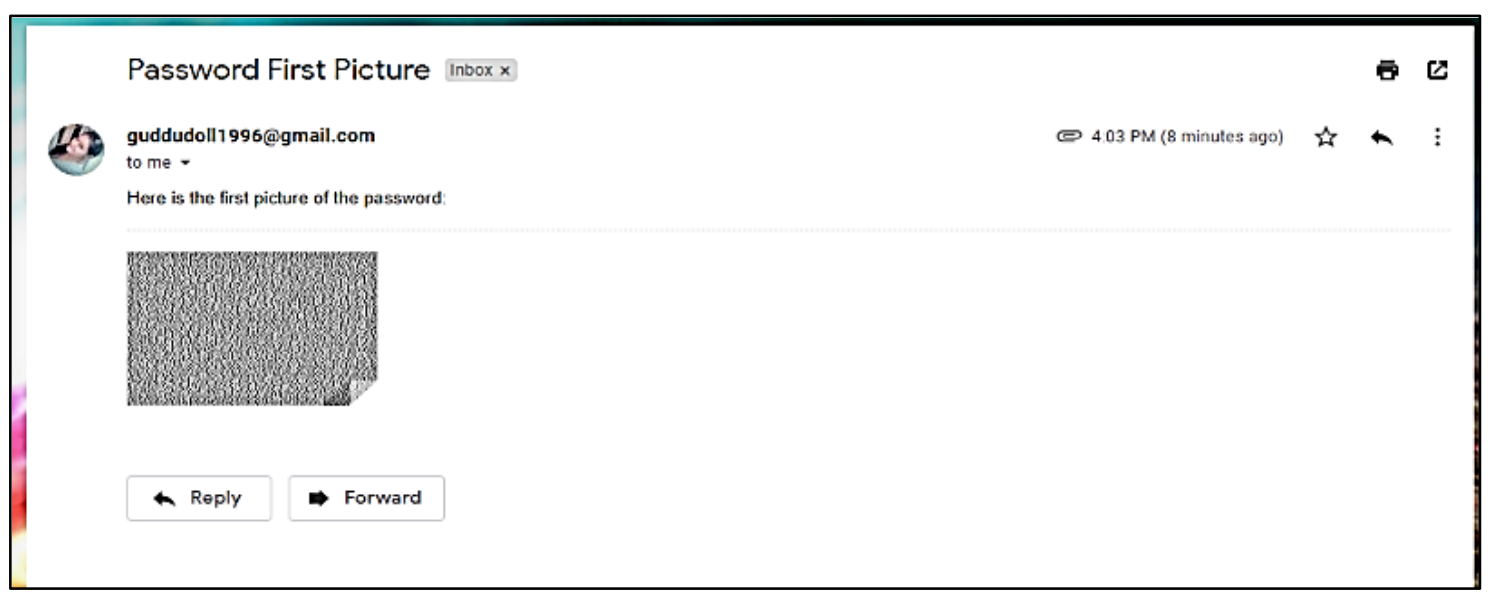

Figure 3 One share password sent to registered client email ID.

\section{Module 3: Authentication}

Once the password is cross-referenced by a server, it provides a source image which has to be entered in the place instead of a code. Hence, the person is authenticated to vote, as shown in Figure 4.

\section{cxcjdr}

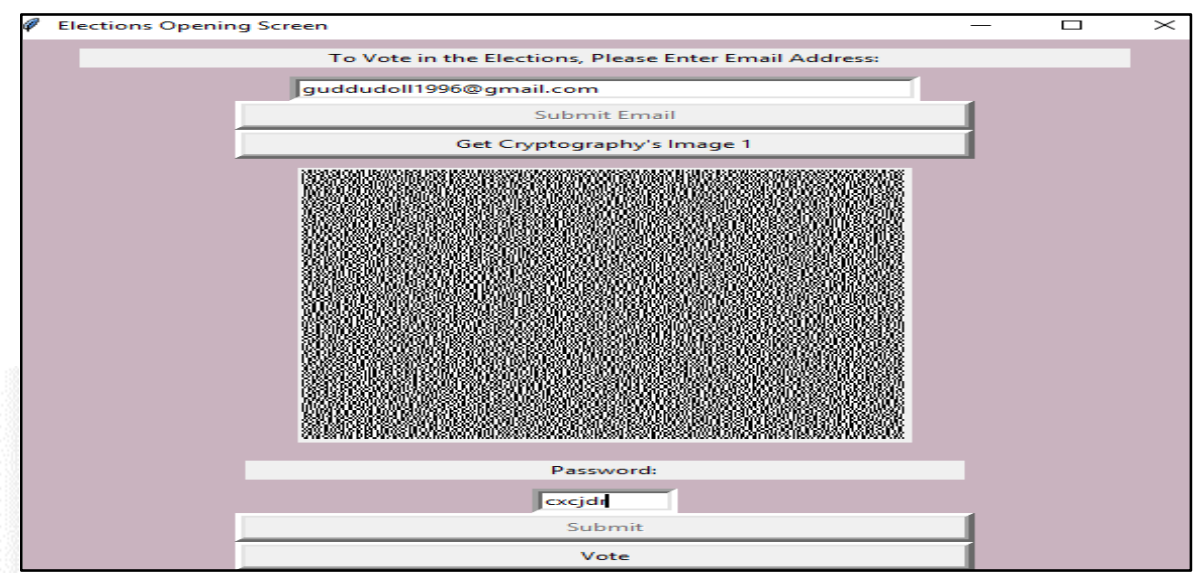

Figure 4 Captcha code password after the merging of 2 codes.

\section{Module 4: Casting the Vote}

Once the person is authenticated with the fulfillment of necessary security norms, the system leads to the voting page for one-time-only voting. There is no chance for forgery, due to double encryption, as shown in Figure 5. 


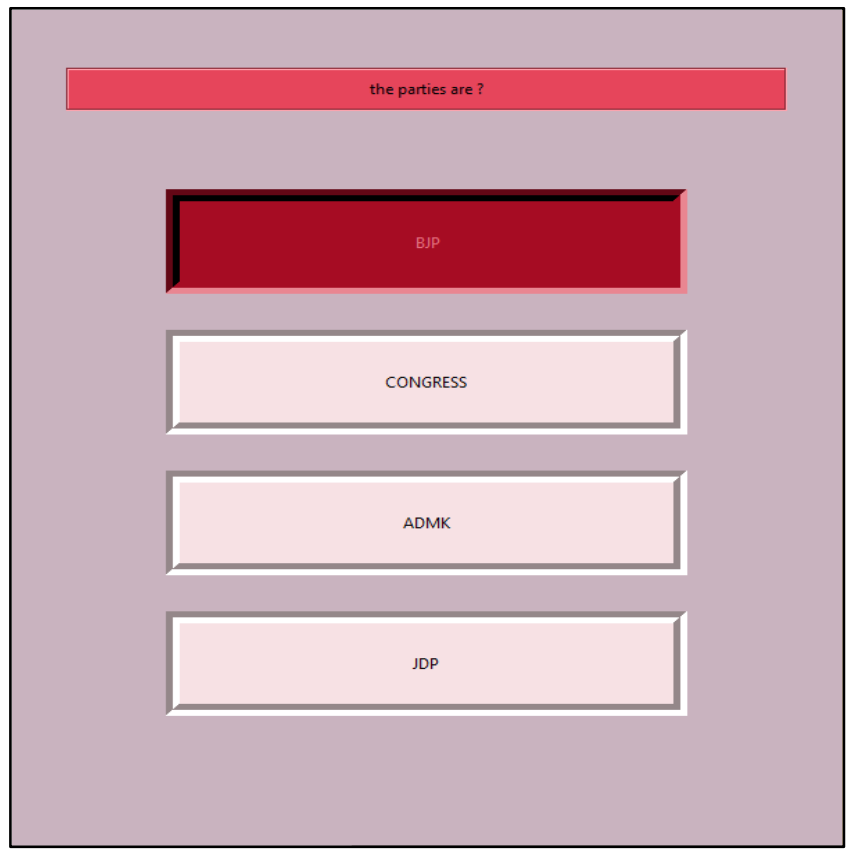

Figure 5 Casting of vote to a desired party.

\section{Module 5: Result analysis}

This module can be monitored on the server end to allow the counting of votes in a faster manner, and also prevents conspiracy, because the server is initiated first, which is liable to access the results, as shown in Figure 6.

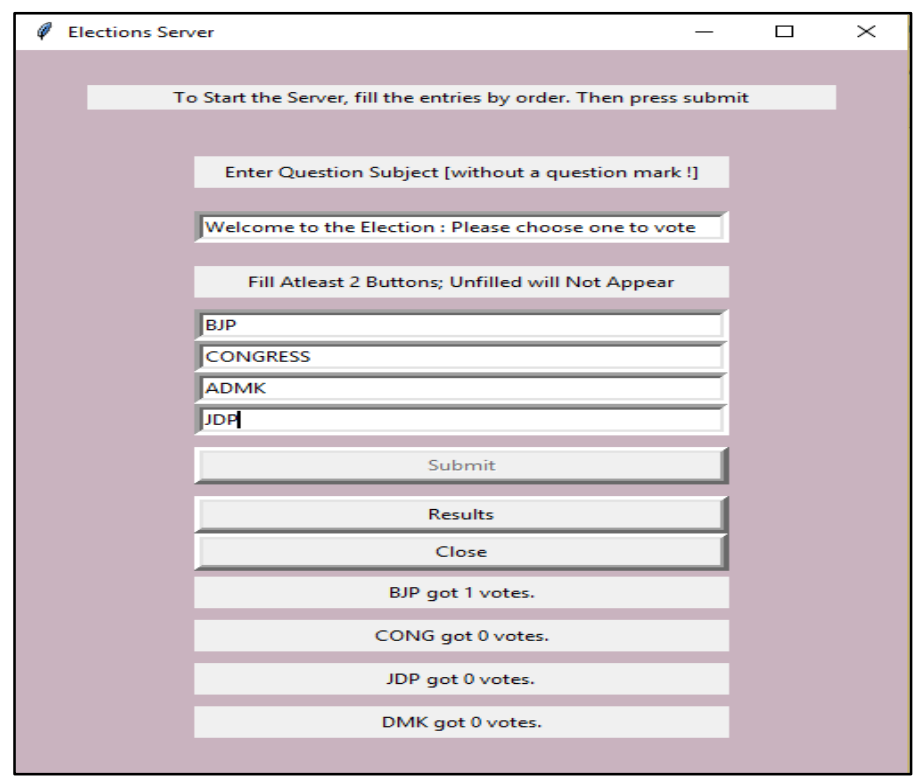

Figure 6 Result analysis from server end. 


\section{Proposed system implementation}

The proposed system is a combination of four major components: server, client, database, and cryptography technique. The server is handled by the local government to enable the various political parties to participate in the election. The database is a mutual platform that is handled on the server end to declare the results to the client. The client platform possesses cryptography [40] which is described in the proposed algorithm, Table 3, for secure voting. The voter undergoes the process of the secure methods initiated by the proposed system for voting on the chosen dates. This work has been implemented based on visual cryptography to help the voting system to be efficient. Our proposed voting system is highly secure and results in better performance, speed, and user-friendliness as compared to the existing systems, as shown in Figure 7. The other requirements, based on geographical conditions, user authentication, and authorization [41], can be modified as per the need of the admin. Hence, the below Figure 9 shows the link between and the connectivity of the 4 main factors involved.

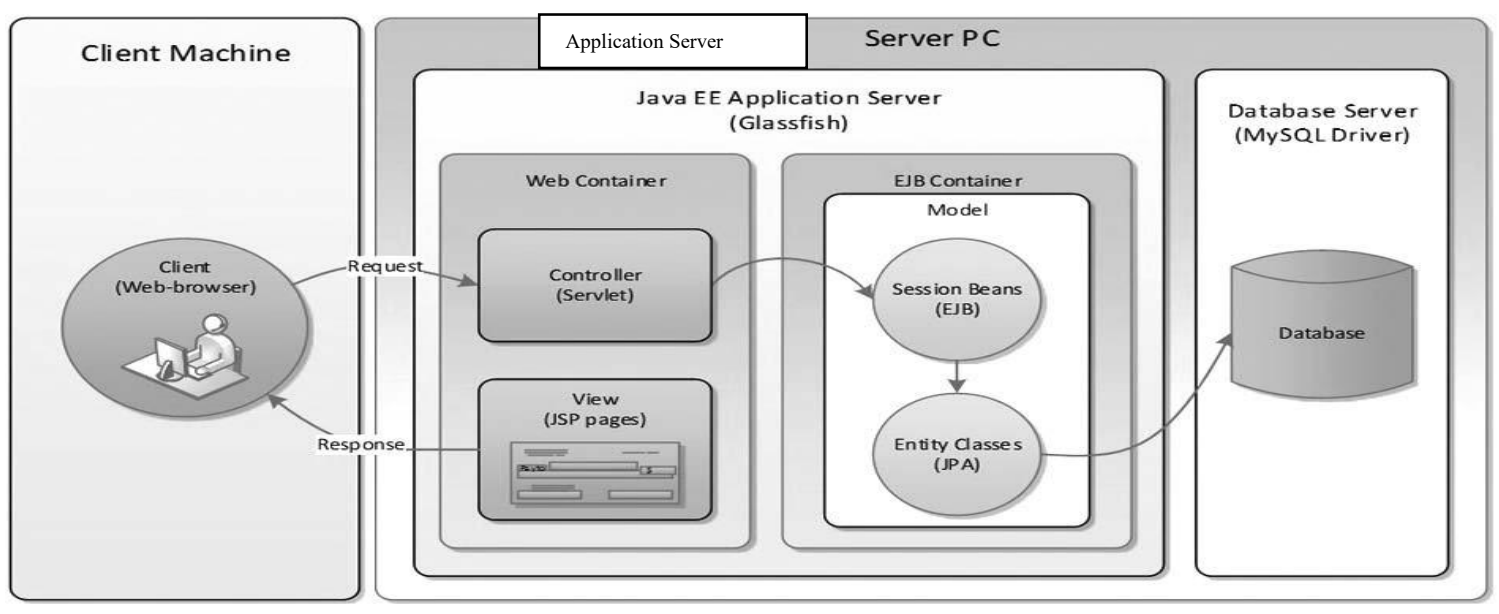

Figure 9 Implementation model.

\section{The role of server}

1. The teams or the parties involved in the voting system are stored.

2. The votes are collected and linked to the database.

3. A connection is established between the client and the database [42]

4. Python code is activated, which helps in the padding.

5. The secure online voting system is developed using Python efficiently, using Jupyter and SQLite3 database server with Anaconda application.

6. Localhost server is used as the back end, and the front end is managed by a hypertext markup language.

7. The processes of the voting system are initialized, activated, monitored, and stored.

\section{The role of client}

1. Server connection establishment.

2. Used by voters to vote for the desired party.

3. One-time voting system.

4. Secure connection between the client and server.

5. User authentication [43].

6. Storage of the casted votes by the client in this connection.

7. Password verification and authorization. 
http://wjst.wu.ac.th

\section{The role of database}

1. A table is created where the email text and the vote text are accommodated and accumulated.

2. The email and the votes are inserted into the votes as the registration is made.

3. Results are also stored in the database for display [44].

4. Verification of the mail and the data is provided by the user.

5. The session is initiated and terminated $[45,46]$.

\section{Graph}

Performance, speed, user-friendliness, and security are the major concerns of the proposed work and are presented in Figure 10 using various test cases which have been passed by time consistency. The below graph is formulated with various performance parameters from the research work mentioned in the literature survey section. Hereby, these points are given completely with the comparison of the existing work and compared with the proposed work. The proposed work has been developed using Python, JavaScript, and HTML coding, and tested with various performance parameters and test cases of 20 different samples.

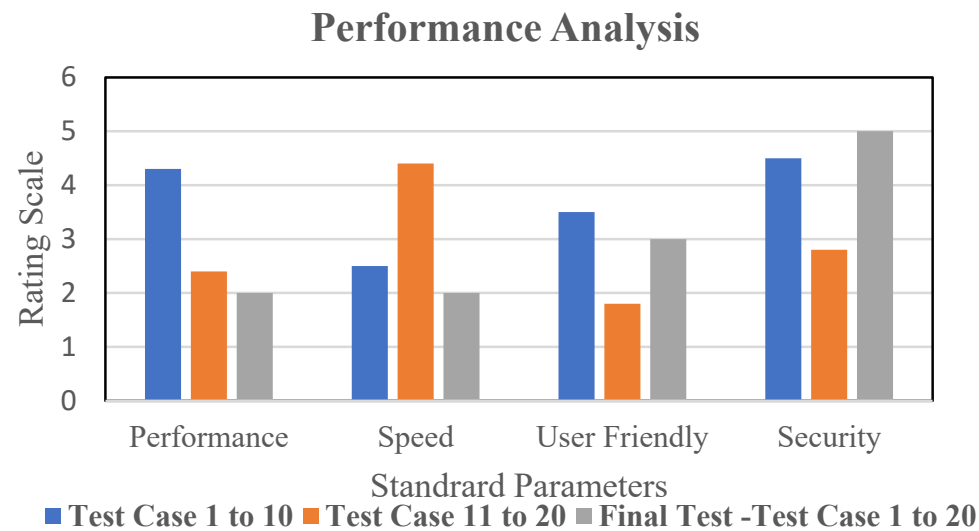

Figure 10 Performance analysis of the proposed secure online voting system with various test cases.

\section{Conclusions}

The proposed system is implemented using visual cryptography for security, efficiency, simplicity, and ease of use to allow all categories of user to cast votes. We have developed a prototype for the proposed system, tested it using various test cases, and analyzed the system performance in a real-time environment. The population living across the globe is increasing and cannot utilize voting opportunities due to busy work schedules, are unable to travel long distances, or have social security issues. The proposed system is novel and successful in overcoming all these limitations of the voters in casting their votes in a secure manner, irrespective of location, gender, social status, or personal issues. For the future, we are upgrading our work so that it can be easily configurable for all platforms and can easily modify the roles and responsibilities as per the user/admin requirements, using a lightweight authentication mechanism which can fulfill the rules and regulations of the local government with internal security and safety measures. Hence, this is a profound work done positively with no false claims made for our system. 
http://wjst.wu.ac.th

\section{References}

[1] SA Alsuhibany. Developing a visual cryptography tool for Arabic text. IEEE Access 2019; 7, 76573-9.

[2] PS Archana and O Ambily. Visual cryptography in internet voting for extended security. Int. J. Eng. Res. Gen. Sci. 2016; 4, 365-8.

[3] AG Bhosale and VS Patil. A $(2,2)$ visual cryptography technique with improved contrast. Inform. Secur. J. Global Perspective 2020; 29, 199-208.

[4] T Chakraborty, S Ghosh, T Ghosh, C Mizan and S Karmakar. (3, 3) Visual cryptography for online certificate authentication. Int. J. Eng. Adv. Tech. 2020; 9, 152-6.

[5] IDC Challener. United States patent. Geothermics 1985; 14, 595-9.

[6] NM Chayal and NP Patel. Review of machine learning and data mining methods to predict different cyberattacks. In: K Kotecha, V Piuri, H Shah and R Patel (Eds.). Data science and intelligent applications. Lecture notes on data engineering and communications technologies. Springer, Singapore, 2021, p. 43-51.

[7] PL Chiu and KH Lee. Threshold visual cryptography schemes with tagged shares. IEEE Access 2020; 8, 111330-46.

[8] K Fisher, R Carback and AT Sherman. Punchscan: Introduction and system definition of a highintegrity election system. In: Proceedings of the $6^{\text {th }}$ Workshop on Privacy Enhancing Technologies, Cambridge, UK. 2006.

[9] Y Guo, X Jia, Q Chu and D Wang. A novel XOR-based threshold visual cryptography with adjustable pixel expansion. Appl. Sci. 2020; 10, 1321.

[10] K Gurunathan and SP Rajagopalan. A stegano - visual cryptography technique for multimedia security. Multimed. Tool. Appl. 2020; 79, 3893-911.

[11] D Hutchison and JC Mitchell. Lecture notes in computer science. Vol. 15-L-systems: Edited by G. Goos and J. Hartmanis. Springer Verlag, Berlin, 1976. vi + 338 pp. Lecture Notes Comput. Sci. $1978 ; 9,242$.

[12] DR Ibrahim, JS The and R Abdullah. Multifactor authentication system based on color visual cryptography, facial recognition, and dragonfly optimization. Inform. Secur. J. Global Perspective 2021; 30, 149-59.

[13] P Jadhav, M Pawar, P Ahire, V Kumar and PJB Kulkarni. Online polling system using extended visual cryptography. Int. J. Eng. Comput. Sci. 2015; 4, 12340-4.

[14] B Jagadeesh and KLSP Reddy. Image security using digital image watermarking and visual cryptography techniques. Int. J. Innovat. Tech. Explor. Eng. 2020; 9, 2386-91.

[15] Jaya, S Malik, A Aggarwal and A Sardana. Novel authentication system using visual cryptography. In: Proceedings of the 2011 World Congress on Information and Communication Technologies, Mumbai, India. 2011, p. 1181-6.

[16] S Jiao, J Feng, Y Gao, T Lei and X Yuan. Visual cryptography in single-pixel imaging. Optic. Express 2019; 28, 7301-13.

[17] GR Kadambi, PB Kumar and V Palade. Lecture Notes in Electrical Engineering 649 Emerging Trends in Photonics, Signal Processing and Communication Engineering Proceedings of ICPSPCT 2018. Springer, Singapore, 2020.

[18] A Kamdi, M Kamble, V Tayade, J Dharne and RN Verma. A novel approach for online voting system using visual cryptography and face detection. Int. J. Adv. Electron. Comput. Sci. 2017; 4, 636.

[19] N Kate and JV Katti. Security of remote voting system based on visual cryptography and SHA. In: Proceedings of the $2^{\text {nd }}$ International Conference on Computing, Communication, Control and Automation, Pune, India. 2016.

[20] T Kohno, A Stubblefield, AD Rubin and DS Wallach. Analysis of an electronic voting system. In: Proceedings of the IEEE Symposium on Security and Privacy, Berkeley, California. 2004, p. 27-40.

[21] R Krimmer and M Volkamer. EVOTE2014. In: Proceedings of the $6^{\text {th }}$ International Conference on Electronic Voting, Bregenz, Austria. 2014. 
http://wjst.wu.ac.th

[22] P Li, J Ma and Q Ma. (t, k, n) XOR-based visual cryptography scheme with essential shadows. $J$. Vis. Comm. Image Represent. 2020; 72, 102911.

[23] P Li, J Ma, L Yin and Q Ma. A construction method of $(2,3)$ visual cryptography scheme. IEEE Access 2020; 8, 32840-9.

[24] P Li, L Yin and J Ma. Visual cryptography scheme with essential participants. Mathematics 2020; 8, 838.

[25] A Makwe and AS Rathore. An empirical study of neural network hyperparameters. In: V Bhateja, SL Peng, SC Satapathy and YD Zhang (Eds.). Advances in intelligent systems and computing. Springer, Singapore, 2021.

[26] SH Masood and S Riza. Trends in selective laser sintering in biomedical engineering. Int. J. Emerg. Trends Eng. Res. 2020; 8, 54-9.

[27] M Melkemi and $\mathrm{K}$ Hammoudi. Voronoi-based image representation applied to binary visual cryptography. Signal Process. Image Comm. 2020; 87, 115913.

[28] OO Mikail, OT Arulogun, EO Omidiora and O Okediran. A survey of cryptographic and steganocryptographic models for secure electronic voting system. Covenant J. Inform. Comm. Tech. 2013; 1, 54-78.

[29] MFM Mursi, GMR Assassa, A Abdelhafez and KAM Samra. On the development of electronic voting: A survey. Int. J. Comput. Appl. 2013; 61, 1-11.

[30] PS Naidu, R Kharat, R Tekade, P Mendhe and V Magade. E-voting system using visual cryptography \& secure multi-party computation. In: Proceedings of the $2^{\text {nd }}$ International Conference on Computing, Communication, Control and Automation, Pune, India. 2016.

[31] RR Nelli, R Mehra, P Madri, S Monica and J Rajeshwari. Anti-phishing I-voting system using visual cryptography. Int. J. Adv. Res. Comput. Comm. Eng. 2017; 6, 113-9.

[32] PK Patidar, R Kushwah and T Chaudhari. Online voting system using visual cryptography and face detection: A survey. Int. J. Res. Appl. Sci. Eng. Tech. 2017; 5, 633-5.

[33] SD Purohit, DS Jat, RC Poonia, S Kumar and S Hiranwal. In: Proceedings of the International Conference on Communication and Computational Technologies. Springer, Singapore, 2021.

[34] HR Pralhad, GV Shivaji, PR Anil, CS Pritamchand and AM Jagtap. Internet voting system using visual cryptography. Int. J. Sci. Res. Develop. 2016; 4, 2022-4.

[35] AB Rajendra and HS Sheshadri. Visual cryptography in internet voting system. In: Proceedings of the $3^{\text {rd }}$ International Conference on Innovative Computing Technology, London, United Kingdom. 2013, p. 60-4.

[36] RM Holla and D Suma. Pipelined parallel rotational visual cryptography (PPRVC). In: Proceedings of the International Conference on Communication and Signal Processing, Chennai, India. 2019, p. 109-13.

[37] L Rura, B Issac and MK Haldar. Implementation and evaluation of steganography based online voting system. Int. J. Electron. Govern. Res. 2016; 12, 71-93.

[38] L Rura, B Issac and MK Haldar. Online voting verification with cryptography and steganography approaches. In: Proceedings of International Conference on Computer Science and Network Technology, Harbin, China. 2011, p. 125-9.

[39] L Rura, B Issac and MK Haldar. Online voting system based on image steganography and visual cryptography. J. Comput. Inform. Tech. 2017; 25, 47-61.

[40] MN Anusha and BK Srinivas. Remote voting system for corporate companies using visual cryptography. Int. J. Adv. Res. Comput. Sci. Software Eng. 2012; 2, 250-4.

[41] GS Mary and SM Kumar. Secure grayscale image communication using significant visual cryptography scheme in real time applications. Multimed. Tool. Appl. 2020; 79, 10363-82.

[42] SK Singh, M Yadav, A Chaudhary and U Singhal. Verifiable color progressive visual cryptography with cheating detection. In: Proceedings of the International Conference on Communication and Computational Technologies Algorithms for Intelligent Systems. Springer, Singapore, 2021, p. 53545.

[43] J Tripathi, A Saini, Kishan, Nikhil and Shazad. Enhanced visual cryptography: An augmented model for image security. Proc. Comput. Sci. 2020; 167, 323-33. 
http://wjst.wu.ac.th

[44] X Wu and CN Yang. Probabilistic color visual cryptography schemes for black and white secret images. J. Vis. Comm. Image Represent. 2020; 70, 102793.

[45] X Yan, F Liu, WQ Yan and Y Lu. Applying visual cryptography to enhance text captchas. Mathematics 2020; 8, 332.

[46] T Zhao and Y Chi. Hierarchical visual cryptography for multisecret images based on a modified phase retrieval algorithm. Multimed. Tool. Appl. 2020; 79, 12165-81. 